\title{
The Experience of Sailboat Crews in Dealing with Emergencies during the Accident in Labuan Bajo, East Nusa Tenggara, Indonesia: A Phenomenology
}

\author{
Yuliana Reginaldis Rosali Krowa ${ }^{1}$, Retty Ratnawati ${ }^{2}$, Yati Sri Hayati ${ }^{3}$ \\ ${ }^{1}$ Master Program of Nursing, Faculty of Medicine, University of Brawijaya, Malang, \\ Indonesia \\ ${ }^{2,3}$ Faculty of Medicine, University of Brawijaya, Malang, Indonesia \\ Email:yulianacrova@gmal.com
}

\begin{abstract}
Ship accidents create emergencies and affect victims, both physically and psychologically. Human error and extreme weather are still the main causes of ship accidents. The crew of the ship, especially the skipper, has an important role and responsibility in ensuring the safety and security of passengers while on the ship. This study is a phenomenology study that aimed to explore the experience of the sailboat crew in dealing with an emergency during an accident in Labuan Bajo, East Nusa Tenggara, Indonesia. Data collection using in-depth interviews with six crew members who have experienced accidents with tourist passengers. The interview result was recorded and transcribed by the researcher and data were then analysed using Interpretative Phenomenological Analysis (IPA) which consisted of six steps of analysis (Reading and re-reading, Initial Noting, Developing Emergent Themes, Searching for Connections Across Emergent Themes, Moving the Next Cases, and Looking for Patterns Across Cases). The results of this study indicate that the crew always tries to save passengers by utilizing the safety equipment available onboard. Although other results indicate that the crew felt that the ship accident was a disaster that occurred outside of the human will, or was not crew negligence.
\end{abstract}

Keyword: Ship Accident, Emergencies on Ship.

\section{A. INTRODUCTION}

Indonesia is the largest maritime country in the world with a sea area of $62 \%$ of the land area, which shows that ships are the main transportation in Indonesia (Louhenapessy \& Febriansyah, 2017). Along with the increase in the number and use of ships, accidents at sea still rank $2^{\text {nd }}$ in terms of incidents of transportation accidents and the number of accidents is increasing (Virk \& Pikora, 2011). Forms of ship accidents include fire, collision, overturning, sinking, and running aground (Bangun \& Hariyono, 2019). Marine transportation accidents in Indonesia in the last 5 years (2015 to April 2019) recorded 76 ship accidents with the highest cause of being a burning ship (30.3\%) which has been completed an accident investigation by the National Transportation Accidents Committee (KNKT, 2019).

The research conducted by Alexandro (2019) and Putra (2018), revealed that the most frequent cause $(80 \%)$ in the investigation results of ship accidents is the factor of human negligence (human error). Accidents can be caused by unsafe actions such as working without proper procedures, and unsafe conditions such as safety 
equipment that does not meet the requirements or standards, in addition to the lack of discipline of the crew in providing and using safety equipment on the ship (Tjahjanto \& Aziz, 2016). Climate change (high winds and high waves) also increases the uncertainty of the magnitude and frequency of slow and rapid disasters (Bangun \& Hariyono, 2019; Triyanti \& Chu, 2017).

Ship accidents create an emergency situation and have an impact on the high number of victims with various levels of injury, environmental damage, and loss of property and psychological impacts (Bangun \& Hariyono, 2019; Sukamto, 2015; Tyas, 2016). In Indonesia, the tourism industry has a positive impact on the national economy, so that marine transportation accidents can reduce the reputation of the country's tourism industry as a whole (Bong, Sugiarto, Lemy, Nursiana, \& Arianti, 2019). In addition, the losses created by ship accidents are often immeasurable, so rescue actions are an important focus (Zheng, $\mathrm{Hu}, \& \mathrm{Xu}, 2017)$. According to Permenhub Nomor 20 Tahun 2015, ship crews are required to report to Ship Safety Inspection Officials (Pejabat Pemeriksa Keselamatan Kapal) regarding ship damage and accidents, each ship must be manned by a ship crew who meets the qualification and competency requirements in accordance with national and international provisions, in particular the captain must meet educational requirements, training, ability, and skills as well as health, and the captain is responsible for the safety, security and order of ships, sailors, and cargo.

Labuan Bajo is the capital of West Manggarai Regency which is located in the western part of East Nusa Tenggara Province. West Manggarai Regency has a land area of 2,947.50 km2, consisting of the mainland of the island of Flores and the big islands (Komodo, Rinca, Longos), as well as other small islands (Kalong, Padar, Kelor, Kanawa, etc.) most of which are tourist destinations (manggaraibaratkab.go.id, 2019). In 2017, Labuan Bajo became one of the ten priority tourism destinations in Indonesia mandated by the president (Kemenpar, 2016). The central and regional governments are striving to promote tourism in Labuan Bajo, and there has been an increase as evidenced by the construction of a number of supporting facilities at tourism sites which have an effect on increasing tourist visits, both domestic and foreign, which is clearly seen in the increased use of hotel rooms in Labuan Bajo (BPS, 2018).

Based on the results of a preliminary study at the Labuan Bajo harbormaster office (Syahbandar), the number of sailboats continues to increase, with an additional 373 ships in 1.5 years. The number of ship accidents recorded from 2018 to March 2019 is 10 accidents. Training for community empowerment to have Ship Skills Certificate (SKK) and Basic Safety Training (BST) in order to have legality in running ships as an effort to improve the quality of human resources, especially ship crews, was only carried out in October 2019 in Labuan Bajo

The results of a preliminary study on a skipper who had experience in ship accidents with tourist passengers, the captain felt helpless and panicked when he found out that his ship had leaked and water had entered the ship. The captain distributed life jackets while calming the passengers. Boat leaks are repaired using 
simple equipment available on board. He also stated that the accident was a disaster and felt traumatized by the accident, so he could not work for three months. The master faces many limitations in an effort to save passengers. This is related to inadequate safety equipment, as well as the possibility of an accident that is considered a disaster. This study aims to explore the experience of ship crews in dealing with emergencies in a ship accident in Labuan Bajo, East Nusa Tenggara, Indonesia.

\section{B. METHOD}

This research is a qualitative research with a phenomenological approach, where the researcher describes the essence of individual experience related to a phenomenon obtained through the interview process. Participants in this study were the crew of a sailboat (Kapal Layar Motor), including the captain and crew member (Anak Buah Kapal). Purposive sampling technique was used in this study by selecting participants based on certain considerations and goals. Participants taken based on certain criteria: (1) crew members who have had an accident with passengers (2) are willing to be research participants. The participant selection process is assisted by officers from the Labuan Bajo Class II Port Administration Unit Office (Syahbandar) and tourism business actors as facilitators, on the grounds that researchers have not known and built a trusting relationship with previous participants.

This research has passed the Ethic Clearance stage from the Health Research Ethics Commission of the Ministry of Health, Kupang Number: LB.02.03/1/0025/2020. Data collection was carried out by in-depth interviews and semi-structured interview techniques on 6 participants, namely 4 people were the skipper and the other 2 were crew members. When meeting with participants, the researcher explains the aims and objectives of the research, the ethics of the study, and agrees on things that cannot be stated in the research and time contract. Participants who expressed consent to participate in the study signed an informed consent.

The researcher began the interview by giving open-ended questions by asking participants' experiences about the ship accident they had experienced. The researcher then asked questions related to the participants' feelings, thoughts, and actions during an emergency in a ship accident. Interviews were recorded using a voice recorder on the smart phone feature and recorded expressions and body language of participants using field notes. Data collection was conducted from February 2020 to May 2020. Data collection was carried out during the Covid-19 pandemic, so it has limited time and number of meetings with participants. After the data was collected, the researcher made transcripts and the data were analyzed using Interpretative Phenomenological Analysis (IPA), which consists of 6 steps, namely Reading and re-reading, Initial Noting, Developing Emergent Themes, Searching for Connections Across Emergent Themes, Moving the Next Cases, and 
Looking for Patterns Across Cases. The results of this study are presented in the form of themes.

\section{RESULT AND DISCUSSION}

The themes resulting from the data analysis in the study are 2 (two) themes, including (1) feeling that a ship accident is a disaster that occurs outside of human will, not because of intention or error from the crew (2) securing guests by using safety equipment available on board as well as the capabilities that are owned.

\section{Theme 1: Feeling that a Ship Accident is a Disaster, Not on Purpose or by Mistake of the Crew}

According to KBBI (Kamus Besar Bahasa Indonesia), a disaster is a sad event that befalls or a disaster. Contextually, the participants felt that an accident was a disaster, a sad situation that came suddenly and occurred outside of human will. In this situation, the participant surrenders to his life, because the accident that occurs is the inevitable will of God. This theme is formed from 6 (six) sub themes.

The first sub-theme is feeling that accidents are events that occur outside human control. Participants feel that an accident is the will of God, it cannot be refused, he and his ship must have an accident. The following is the participant's statement:

"... maybe it's power from God, I'll just accept it I'll say..."

"...maybe it's from God I said, that's why there is..." (P2)

The second sub-theme is to feel that life and death are in God's hands. Contextually, the participant felt that even if he had to die in a boat accident, it was God's will that he could not refuse. Whatever happened to the participant, whether he survived and lived, or died in an accident, he left everything to God. Following are participant statements describing these sub-themes:

"...I also surrender to the Almighty...My life and death are in the hands of God..."

The third sub-theme is feeling that an accident is a disaster. Contextually, the participants felt that the accident they experienced was a sad event or situation. Participants feel that the accident is a disaster or calamity that befell him while at sea even though in his daily life the sea and ships are his place of life. Following are participant statements describing these sub-themes:

"...the next day there were big winds and waves while we were still on the road and in the middle of the road we just got a disaster..." (P3)

"...but it's a disaster, the responsibility shouldn't be like that, don't underestimate that we're used to in one place, every day we go through there but the name is still a disaster for the captain, so keep your eyes peeled..." (P6)

The fourth sub-theme is feeling that accidents happen suddenly and cannot be known. Participants feel that the accident they experienced happened suddenly or suddenly. The incidence of accidents cannot be predicted so that it also makes participants feel panic about it, even though the participants have made 
preparations for the accident. Following are participant statements describing these sub-themes:

"... it was an accident we don't know, suddenly appeared..." (P4)

"...indeed at that time I had no thoughts of it (there would be an accident), because it suddenly reversed, I panicked..." (P4)

"...there are preparations, but the name is a disaster, we don't know, because it happened too suddenly..." (P4)

The fifth sub-theme is feeling that ship accidents occur because of bad luck. Contextually, participants felt that the ship accident they experienced was bad luck or because they were not lucky at the time. His rescue efforts are hampered by damaged equipment due to his bad luck. The following is the participant's statement:

"...there is at a time, it's just that, it's unlucky, I also think it's unlucky too, once the engine starter is pulled, the rope breaks..." (P5)

"...but the incident which was about 200 meters from Bidadari (an island) did I think about it, what about it, I consider it unlucky, bad luck, because it just came suddenly..." (P5)

The sixth sub-theme is feeling that an accident is not an accident. Contextually, the participants felt that the accident was not something the crew did deliberately. According to the participants, a ship accident was a natural disaster that happened by itself. Participants feel that the accident is not their fault. Below is a statement describing this final sub-theme:

"...this is also not on purpose so this is called a disaster, a natural disaster..." (P5)

"...That's why they're not, right, they're not angry. So it's not my fault, I told you..." (P5)

\section{Theme 2: Secure Guests Using the Safety Equipment Available on Board and their Capabilities}

According to KBBI literally, the word safe means that being free from danger, and securing means protecting, saving. Contextually, participants try to save passengers immediately, either by using safety equipment or without using equipment. This theme is formed from 2 (two) sub themes.

The first sub-theme is trying to save passengers by using equipment. Participants carry out rescue actions quickly, using the safety equipment available on board. Participants want all passengers and crew to survive the accident. Safety equipment used includes speedboats, life rafts, life jackets. Following are participant statements describing these sub-themes:

"...I immediately saved this, the speedboat to secure guests..." (P1)

"...I immediately threw it (life jacket) as well when it was upside down so it wouldn't disappear, drown..." (P2)

"...at that time, the first to leave the ship was the crew, then the crew saved the guests, and gave life jackets..." (P3)

"...but, there are all the life jackets, immediately divided all..." (P4) 
"...I thought save it, cut the life raft, just arrange the crew members, all use life jackets, all of our safety equipment are distributed in the sea so they are easy to condition..." (P6)

The second sub-theme is trying to save passengers even without using safety equipment. Participants try to save the ship's passengers, exert their abilities so that the passengers are safe, even without using safety equipment. Following are participant statements describing these sub-themes:

"...yes, I was afraid my guests would disappear so I quickly pulled all the life rafts so that they could open, but I did dive first, the rope was carried, while I was holding the rope I was afraid I would be washed away, I pulled it open to become a house, I said come on. Brothers-sisters enter here so that they don't part with their friends..." (P2)

"... I try, I swim, dive, take it for women who don't know swimming, lift up..." (P4)

"...the guest also doesn't know how to swim, only I can be there. So thank God I didn't panic, I tried to save them and thank goodness everyone survived. After about an hour and a half we floated and our position was all on the boat..." (P5)

Transportation accidents are one of the risks of disaster threats that can cause casualties, property, the environment, and have a psychological impact (Kementerian Perhubungan, 2019; Sukamto, 2015; Tyas, 2016). Ship accidents are events or events that befell a ship and its crew and cargo, which are caused by human error (human error), damage to ship engines, fires and collisions, as well as natural or weather factors (Ar, 2015).

The first theme is the feeling that a ship accident is a disaster, not because of intention or fault of the crew. The crew felt that they were not at fault for the ship accident. The National Transportation Safety Committee (NTSC) defines an emergency on a ship as an extraordinary situation caused by human negligence (human error), natural phenomena or circumstances that occur beyond human ability (force majeure or act of God), so that it can be dangerous. ship safety, souls of people who are on board, cargo or polluting the marine environment (KNKT, 2016). There are many studies that show that the biggest cause of ship accidents is human factors or human error. The results of research conducted by Alexandro (2019) and Putra (2018), revealed that the most frequent cause (80\%) in the investigation results of ship accidents is the factor of human negligence (human error).

Other studies have found that ship captains take risks to keep sailing even though the weather is less favourable (Pandiangan, 2020). In this study, it was found that participants stated that the damage to the equipment on the ship was due to bad luck. Whereas accidents can be caused by unsafe actions such as working without proper procedures, and unsafe conditions such as safety equipment that does not meet the requirements or standards, besides the low discipline of crew members in providing and using safety equipment on ships (Tjahjanto \& Aziz, 2016). Therefore, the crew of the ship should have a good knowledge and understanding of their duties, responsibilities and roles on board, and be able to guarantee the safety and security of passengers while on the ship. This can be done by increasing discipline, especially in meeting the ship's eligibility requirements for sailing. 
Furthermore, on the second theme, namely securing guests using the safety equipment available on the ship and the capabilities they have. In the context of this research, the crew tried to save the first passenger and this was done quickly. Judging from the laws and regulations in Indonesia, namely Permenhub Number 20 of 2015, the skipper is responsible for the safety, security and order of ships and their cargo, both human and goods. The crew uses the safety equipment available on board such as life jackets, life rafts and speedboats. Safety equipment is important in emergency relief efforts to minimize losses (Lestari, Hasugian, \& Wahyuni, 2020). Equipment needed in an emergency on board includes Breathing Apparatus I Alarms, Fireman Out Fit - Stretcher, communication tools, Life Saving Appliances (life jackets, life rats, emergency signals) and other rescue equipment (Gaffar et al., 2015).

The crew is one of the important points in an emergency response plan, namely personnel, as stated by Setyowati et al., (2016), that the emergency response plan consisting of risk assessment, personnel, emergency facilities, training, emergency procedures and information dissemination is efforts to overcome various impacts caused by an incident, including on a ship accident. Emergency response is a series of activities that are carried out immediately when an incident or incident occurs which creates an emergency situation to deal with the bad effects it causes (UNDP, 2012). Emergency response is based on a system or pattern that is able to integrate activities and efforts carried out quickly, precisely and under control (Gaffar et al., 2015). Each crew member, especially the captain, must be able to carry out their duties, responsibilities, and roles based on established standard operating procedures, identify or assess risks that may occur on board, and improve skills, especially ship safety management. In the context of this research, limited safety equipment does not prevent the crew from trying to save passengers. The ability to swim and dive is used to keep passengers safe from accidents.

\section{CONCLUSION}

Based on the description above, it can be concluded that in an emergency faced by a ship crew in a ship accident, the crew's immediate action is to save passengers. Rescue measures are carried out using safety equipment such as life jackets, life rafts, and speedboats. Despite the limitations of safety equipment, the crew still exerts their ability by swimming and diving to save passengers. However, the crew felt that the ship accident which he and his passengers experienced was a disaster that occurred outside of human intervention, as well as bad luck. In other previous studies, it was stated that human error was the biggest cause of ship accidents. Further and in-depth research related to accidents as a disaster for the crew is very necessary.

\section{ACKNOWLEDGEMENT}

Researchers would like to thank the Lembaga Pengelola Dana Pendidikan (LPDP) for financing this research. 


\section{REFERENCES}

1. Alexandro, V. H., \& Rahmawati, M. (2019). Pertanggungjawaban pidana terhadap kecelakaan kapal akibat tidak laik laut. Jurnal Hukum Adigama.

2. Ar, H. T. (2015). Manajemen Keselamatan Maritim dan Upaya Pencegahan Kecelakaan Kapal ke Titik Nol (Zero Accident). Jurnal Ilmiah Widya, 3(2), 110116.

3. Bangun, G. A. A., \& Hariyono, W. (2019). Analisis Penerapan Keselamatan dan Kesehatan Kerja (K3) Pada Kapal Penumpang di PT PELNI Semarang. In Seminar dan Konferensi Nasioanl IDEC (pp. 1-6). Surakarta.

4. Bong, S., Sugiarto, Lemy, D. M., Nursiana, A., \& Arianti, S. P. (2019). Manajemen risiko, krisis, dan bencana untuk industri pariwisata yang berkelanjutan. Jakarta: PT Gramedia Pustaka Utama.

5. BPS. (2018). Badan Pusat Statistik Kabupaten Manggarai Barat. Retrieved from https://manggaraibaratkab.bps.go.id/dynamictable/2018/11/06/167/tingkatpenghunian-kamar-menurut-bulan-di-kabupaten-manggarai-barat-20152017.html.

6. Gaffar, M. A., Nadir, M., Adam, Lendri, Sulaiman, M., Husniati, \& Erna. (2015). Prosedur Darurat dan SAR (Vol. 4). Pangkep: P3AI Politani Pangkep.

7. Kemenpar. (2016). Kebijakan Pengembangan Destinasi Pariwisata Indonesia 20162019. Jakarta.

8. Kementerian Perhubungan. (2019). Laporan Kinerja Kementerian Perhubungan Tahun 2018. Jakarta.

9. KNKT. (2016). Maritime Glossary. Retrieved from http://knkt.dephub.go.id/knkt/ntsc_maritime/maritime_glossary.htm

10. Lestari, E. G. T., Hasugian, S., \& Wahyuni, I. S. (2020). Analisis Pengetahuan, Sikap, Dan Perilaku Anak Buah Kapal Deck Terhadap Penggunaan Personal Protective Equipment di MV. Sendang Mas. Dinamika Bahari, 1(1), 15-20.

11. Louhenapessy, B. B., \& Febriansyah, H. (2017). The Standardization Of The Ship National Industries In Indonesia. Jurnal Standardisasi, 19(1), 11-24.

12. manggaraibaratkab.go.id. (2019). Profil Daerah (Geografis). Retrieved from https://manggaraibaratkab.go.id/profil-daerah/geografis

13. Pandiangan, A. S. (2020). Gambaran Pengetahuan Kenavigasian dan Tanggap Darurat pada Nakhoda Kapal Transportasi Penyeberangan Danau Toba Tahun 2019. Universitas Sumatera Utara, Sumatera Utara.

14. Putra, Y. S. (2018). Rekonstruksi Hukum Transportasi Perairan Terhadap Keselamatan dan Keamanan Penumpang dan Barang. Jurnal Ilmu Hukum, 4(2), 693-700.

15. Setyowati, L., Suroto, \& Kurniawan, B. (2016). Analisis Implementasi Rencana Tanggap Darurat (Emergency Response Plan) pada Kapal Penumpang X. Jurnal Kesehatan Masyarakat, 4(3), 478-486.

16. Sukamto. (2015). Manajemen antisipasi bencana. Yogyakarta: Graha Ilmu.

17. Tjahjanto, R., \& Aziz, I. (2016). Analisis Penyebab Terjadinya Kecelakaan Kerja Di Atas Kapal Mv . Cs Brave. KAPAL, 13(1), 13-18. 
18. Triyanti, A., \& Chu, E. (2017). A survey of governance approaches to ecosystembased disaster risk reduction: Current gaps and future directions. International Journal of Disaster Risk Reduction, (May), 1-11. https://doi.org/10.1016/j.ijdrr.2017.11.005

19. Tyas, M. D. C. (2016). Keperawatan Kegawatdaruratan \& Manajemen Bencana. Jakarta Selatan: Pusdik SDM Kesehatan Kementerian Kesehatan Republik Indonesia.

20. UNDP. (2012). Panduan: Pengurangan Risiko Bencana Berbasis Komunitas. United Nations Development Programme and Government of Indonesia.

21. Virk, A., \& Pikora, T. J. (2011). Developing a tool to measure safe recreational boating practice. Accident Analysis and Prevention, 43(1), 447-450. https://doi.org/10.1016/j.aap.2010.09.016

22. Zheng, L., Hu, J., \& Xu, S. (2017). Marine Search And Rescue Of Uav In LongDistance Security Modeling Simulation. Polish Maritime Research, 24(95), 192-199. 